\title{
Copaifera multijuga, Copaifera pubiflora and Copaifera trapezifolia Oleoresins: Chemical Characterization and in vitro Cytotoxic Potential against Tumoral Cell Lines
}

\author{
Luiza J. Carneiro, ${ }^{a}$ Thercius O. Tasso, ${ }^{a}$ Mario F. C. Santos, ${ }^{a}$ Mirian O. Goulart, ${ }^{a}$ \\ Raquel A. dos Santos, ${ }^{a}$ Jairo K. Bastos, ${ }^{b}$ Jonas J. M da Silva, ${ }^{b, c}$ Antônio E. M. Crotti, ${ }^{c}$ \\ Renato L. T. Parreira, ${ }^{\oplus a}$ Renato P. Orenha, ${ }^{\oplus a}$ Rodrigo C. S. Veneziani ${ }^{\odot *, a}$ and \\ Sérgio R. Ambrósio*,a \\ ${ }^{a}$ Núcleo de Pesquisa em Ciências Exatas e Tecnológicas, Universidade de Franca, \\ Av. Dr. Armando de Salles Oliveira, 201, 14404-600 Franca-SP, Brazil \\ ${ }^{b}$ Departamento de Física e Química, Faculdade de Ciências Farmacêuticas de Ribeirão Preto, \\ Universidade de São Paulo, Av. do Café s/n, 14040-903 Ribeirão Preto-SP, Brazil \\ 'Departamento de Química, Faculdade de Filosofia, Ciências e Letras de Ribeirão Preto, \\ Universidade de São Paulo, Av. do Café s/n, 14040-903 Ribeirão Preto-SP, Brazil
}

\begin{abstract}
Copaifera species (Fabaceae) comprises approximately 70 species of large trees, from which 16 can be found in Brazil. The oleoresins obtained from their trunk are widely used in Brazilian folk medicine, which display important antitumoral potential. Chemically, these oleoresins are mainly composed of a mixture of sesquiterpenes and diterpenes. In this paper we are describing the isolation and identification of 12 already known terpenes from oleoresins obtained from three different Copaifera species (C. multijuga, C. pubiflora and C. trapezifolia) and 2 novel diterpenes (ent-16-hidroxy-3,13 clerodadien-15,18-dioic acid and ent-labda-5,13-dien-15-oic acid) from C. trapezifolia. Both new compounds were identified by nuclear magnetic resonance (NMR) spectroscopic ( ${ }^{1} \mathrm{H}$ and ${ }^{13} \mathrm{C}$ NMR, correlation ${ }^{1} \mathrm{H}-{ }^{1} \mathrm{H}$ (COSY), heteronuclear multiple quantum coherence (HMQC) and heteronuclear multiple bond correlation (HMBC)) and by high-resolution electrospray ionization mass spectrometry (HR-ESIMS) analyses. The cytotoxic potential of these oleoresins, their main non-volatile compounds and their volatile compound fractions were evaluated against a panel of tumoral (MCF-7, ACP01, A549, HeLa) and normal cell lines (MCF-10A, GM07492-A) through XTT (tetrazolium salt) and SRB (sulforhodamine B) assays. The novel diterpene ent-labda-5,13-dien-15-oic acid displayed relevant cytotoxic effect against most of the cancer cell lines with mean inhibitory concentration $\left(\mathrm{IC}_{50}\right)$ values ranging from $3.57 \pm 1.12$ to $22.56 \pm 1.03 \mu \mathrm{g} \mathrm{mL}^{-1}$, and a high selectivity level in both assays.
\end{abstract}

Keywords: Copaifera spp., terpenes, tumor cell lines, cytotoxicity, oleoresins

\section{Introduction}

The Copaifera L. genus occur throughout South America, Africa and Asia. It belongs to the Fabaceae family and comprises approximately 70 species of large trees, from which 16 can be found in Brazil. ${ }^{1}$ The oleoresins obtained from their trunk are widely used in Brazilian folk medicine, and many folk uses were corroborated by researchers, including: anti-inflammatory, anticancer, wound healing, antiparasitic, and antimicrobial properties, among others. ${ }^{1-3}$ Chemically, these oleoresins are composed of a

*e-mail: rodrigo.veneziani@unifran.edu.br; sergio.ambrosio@unifran.edu.br diversified mixture of terpenoids, mainly sesquiterpenes and diterpenes, which are the major constituents from their volatile and non-volatile fractions, respectively. ${ }^{4}$

Among all ethnopharmacological applications that have been described for Copaifera species oleoresins, their antitumor effect stands out since its efficacy has been proven. Lima et al..$^{5}$ evaluated the anticancer activity of Copaifera multijuga oleoresin against melanoma cells and its inhibition of lung metastasis. The results of this study showed that this oleoresin and its fractions display tumoricidal activity in the melanoma cell line, once oral treatment of $2.0 \mathrm{~g} \mathrm{~kg}^{-1}$ reduced tumor growth and its weight by 58 and $76 \%$, respectively. Gomes et al. ${ }^{6}$ investigated 
the antineoplasic activity of Copaifera multijuga oleoresin and its hexanic and chloroformic fractions against ascitic and solid Ehrlich tumor, demonstrating that it promoted inhibition of the solid tumor on paws after three days of oral treatment $\left(150 \mathrm{mg} \mathrm{kg}^{-1}\right)$, which was similar to the control group (vincristine $0.5 \mathrm{mg} \mathrm{kg}^{-1}$ ).

Despite of the fact that some studies pointed out the antitumoral efficacy of these natural products, most related scientific research were only performed with crude oleoresins of Copaifera multijuga and its fractions. Moreover, it can also be observed that only a limited number of studies were carried out to evaluate the cytotoxic potential of their constituents, thus denoting the need for further investigations aiming to better establish which compounds are related with the cytotoxic and antitumor potential previously reported for the Copaifera oleoresins. ${ }^{1}$

In this regard, and as part of ongoing efforts to explore the chemical and biological properties of Brazilian Copaifera, we are reporting the chemical characterization of the oleoresins obtained from three different species of two different regions of Brazil: C. multijuga, C. pubiflora (from the north) and C. trapezifolia (from southeast), as well as the evaluation of the in vitro cytotoxic potential of diterpenes and sequiterpenes isolated from these oleoresins against a panel of cancer cell lines.

\section{Experimental}

\section{General}

High-performance liquid chromatography (HPLC) analyses were performed using an on-line HPLC Shimadzu system coupled with a photodiode array detector (DAD, SPD-M20A) and a Shim-pack CLC-ODS column $(250 \times 4.6 \mathrm{~mm}$ internal diameter (i.d.), $5 \mu \mathrm{m}$; Shimadzu). High-resolution mass spectrometry (HRMS) was performed by direct injection in electrospray ionization time-of-flight (ESI-TOF) system mass spectrometer (Waters-XEVO-G2XSQTOF). Nuclear magnetic resonance (NMR) spectra were obtained at $25^{\circ} \mathrm{C}$ both at $400 \mathrm{MHz}$ $\left({ }^{1} \mathrm{H}\right)$ and at $100 \mathrm{MHz}\left({ }^{13} \mathrm{C}\right)$ Bruker spectrometer. The ${ }^{1} \mathrm{H}$ chemical shifts were referenced to the residual $\mathrm{CDCl}_{3}$ and $\mathrm{CD}_{3} \mathrm{OD}$ signals $(\delta 7.26,3.30$ and 4.95 , respectively) and ${ }^{13} \mathrm{C}$ chemical shifts were referenced to the $\mathrm{CDCl}_{3}$ and $\mathrm{CD}_{3} \mathrm{OD}$ solvent peaks ( $\delta 77.0$ and 49.5 , respectively). Classic and vacuum liquid chromatography $(\mathrm{CC}$ and VLC, respectively; glass columns of $450 \times 25 \mathrm{~mm}$ and $50-100 \mathrm{~mm}$ i.d.) were used to purify the terpenes using silica gel 60 (Merck, 9385) and silica gel 60H (Merck, 7736). Acetonitrile (chromatographic grade) was supplied by Mallinkrodt Baker Inc. (Phillipsburg, NJ, USA), water was purified with a Milli-Q-plus filter system (Millipore, Bedford, MA, USA) and commercial hexanes, ethyl acetate (EtOAc) and chloroform were purified by distillation in our facilities. The tetrazolium salt (XTT) assay was performed using the Cell Proliferation Kit II (Roche ${ }^{\circledR}$, Rotkreuz, Switzerland). Gas chromatography mass spectrometry (GC-MS) was performed using a Shimadzu-QP 2010 gas chromatography equipped with an automatic injector AOC-20Si, a DB-5 column $(30 \mathrm{~m} \times 0.25 \mathrm{~mm} \times 0.25 \mathrm{~mm})$, and a mass spectrometer of the same company, which was operated in the electron ionization (EI) mode (beam energy voltage $70 \mathrm{eV}$ ). Hydrogen at a flow rate of $1.8 \mathrm{~mL} \mathrm{~min}{ }^{-1}$ was employed as carrier gas. The main constituents were identified by comparison of the obtained mass spectra of the peaks with those either reported in the literature or available in the Wiley NBS data system library. Optical rotations were measured with a Jasco P-2000 polarimeter (serial No. A104161232) at $25^{\circ} \mathrm{C}$.

\section{Plant materials}

The oleoresins studied in the present study were collected by Jonas J. M. da Silva in different regions of Brazil, as following: Copaifera multijuga (OCm, Manacapuru, Amazonas State, $03^{\circ} 11.858^{\prime}$ S, 6035.437’ W), Copaifera pubiflora (OCp, Mucajaí, Roraima State, $02^{\circ} 36.205^{\prime} \mathrm{N}, 60^{\circ} 56.767^{\prime} \mathrm{W}$ ) and Copaifera trapezifolia (OCt, São Miguel Arcanjo, São Paulo State, $24^{\circ} 03.421^{\prime} S$, $47^{\circ} 59.340^{\prime} \mathrm{W}$ ). The botanical identification of C. multijuga and C. pubiflora was carried out by Silvane Tavares Rodrigues at the IAN Herbarium (EMBRAPA Amazônia Oriental), and the voucher specimens were deposited under the registry No. 180069 and 180231, respectively. C. trapezifolia specimen was identified by Milton Groppo Junior at the SPFR Herbarium (University of São Paulo) under the registry No. NID 47/2014.

The authorization to undertake scientific studies with plant species from Brazilian biodiversity was requested to the Brazilian Council for Authorization and Information on Biodiversity (SISBIO/ICMBio/MMA/BRASIL) and the Genetic Heritage Management (CGEN/MMA/BRASIL) and were issued under No. 35143-1 and 010225/2014-5, respectively.

\section{Isolation of terpenes from C. multijuga oleoresin}

Hundred grams of OCm were firstly incorporated in about $40 \mathrm{~g}$ of silica gel $60 \mathrm{H}$ and then chromatographed on VLC (750 g; silica gel $60 \mathrm{H})$. In this procedure, 11 fractions were collected $(1.5 \mathrm{~L}$ each) using the 
following gradients: hexanes (OCm1; $79.78 \mathrm{~g})$, hexanes/ EtOAc 9:1 (OCm2; $827.00 \mathrm{mg})$, hexanes/EtOAc 4:1 (OCm3; $4.99 \mathrm{~g})$, hexanes/EtOAc 7:3 (OCm4; $2.09 \mathrm{~g})$, hexanes/EtOAc 3:2 (OCm5; $545.00 \mathrm{mg})$, hexanes/EtOAc 1:1 (OCm6; $398.00 \mathrm{mg}$ ), hexanes/EtOAc 2:3 (OCm7; $62.00 \mathrm{mg}$ ), hexanes/EtOAc 3:7 (OCm8; $24.00 \mathrm{mg}$ ), hexanes/EtOAc 1:4 (OCm9; $10.00 \mathrm{mg})$, hexanes/EtOAc 1:9 (OCm10; $8.00 \mathrm{mg})$ and EtOAc (OCm11; $7.00 \mathrm{mg})$. An aliquot of OCm1 was firstly analyzed by GC-MS to identify the main volatile compounds. Fractions OCm4 and OCm6 displayed single peak chromatograms by HPLC-DAD analyses, leading to the identification of compounds codified as $\mathbf{C m 1}$ (ent-3 $\beta$-acetoxy copalic

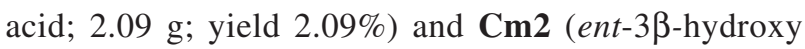
copalic acid; $398.00 \mathrm{mg}$; yield $0.398 \%$ ), respectively, after ${ }^{1} \mathrm{H}$ and ${ }^{13} \mathrm{C}$ NMR analyses. Fraction $\mathrm{OCm} 2(827.00 \mathrm{mg})$ was subjected to separation by CC (silica gel $60 ; 75.0 \mathrm{~g}$ ) using hexanes/chloroform/EtOAc in the proportion 8:1:1 to furnish $32.00 \mathrm{mg}$ of compound $\mathbf{C m} \mathbf{3}$ (caryophyllene oxide; yield $0.032 \%$ ).

Fraction OCm3 was also chromatographed on VLC over silica gel $60 \mathrm{H}(200.0 \mathrm{~g})$ with increasing amounts of 4\% EtOAc (hexanes to hexanes/EtOAc 17:8; $200 \mathrm{~mL}$ each fraction), resulting in nine additional fractions (OCm3.1-OCm3.9). Analysis of the subfraction OCm3.9 by HPLC-DAD also denoted a single peak chromatographic profile, thus allowing to identify ent-copalic acid (Cm4; $151.00 \mathrm{mg}$; yield 0.151\%). Compounds Cm5 ((-)-epicubenol; $34.00 \mathrm{mg}$; yield 0.034\%) and Cm6 ((-)-torreyol; $7.90 \mathrm{mg}$; yield $0.0079 \%)$ were obtained through CC using silica gel $60(70.0 \mathrm{~g})$ and an isocratic mobile phase (hexanes/chloroform/EtOAc 9.5:0.25:0.25 and hexanes/EtOAc 9:1), from subfractions OCm3.5 and OCm3.6, respectively.

The fraction $\mathrm{OCm} 5$ was chromatographed on $\mathrm{CC}$ using $80.0 \mathrm{~g}$ of silica gel 60 and mixture of hexane/ EtOAc/dichloromethane 3:6:1 as mobile phase, furnishing compound ent-agatic acid $(55.50 \mathrm{mg} ; \mathbf{C m} 7$; yield $0.0555 \%)$. Finally, compound $\mathbf{C m 8}(2.30 \mathrm{mg}$; ent-3 $\beta, 18$-dihidroxy-8(17), 13 labdadiene-15-oic acid; $0.0023 \%$ ) was purified after washing the fraction OCm8 with cold hexanes.

\section{Isolation of terpenes from C. pubiflora oleoresin}

The procedure to isolate and/or identify the main chemical constituents of $C$. pubiflora was performed submitting the oleoresin (100.0 g, incorporated in about $40 \mathrm{~g}$ of silica gel $60 \mathrm{H})$ through VLC $(600.0 \mathrm{~g}$ of silica gel $60 \mathrm{H}$ ) using the following mobile phase gradients (1.5 L each fraction): hexanes (OCp1; $43.53 \mathrm{~g}$ ), hexanes/
EtOAc 4:1 (OCp2; $44.50 \mathrm{~g}$ ), hexanes/EtOAc 7:3 (OCp3; $3.07 \mathrm{~g}$ ), hexanes/EtOAc 3:2 (OCp4; $2.83 \mathrm{~g}$ ), hexanes/ EtOAc 1:1 (OCp5; $888.00 \mathrm{mg}$ ), hexanes/EtOAc 3:7 (OCp6; $68.00 \mathrm{mg}$ ), hexanes/EtOAc 1:9 (OCp7; $73.00 \mathrm{mg}$ ) and EtOAc (OCp8; $8.70 \mathrm{mg})$.

Initially, the main volatile compounds of $C$. pubiflora were identified by analysis of OCp1 through CG-MS. Following, fraction $\mathrm{OCp} 2$ was also chromatographed using VLC (600.0 g of silica gel $60 \mathrm{H})$ with increasing amounts of $2 \%$ EtOAc in hexanes (hexanes to hexanes/ EtOAc 8:2) furnishing 11 sub-fractions $(250.0 \mathrm{~mL}$ each; OCp2.1-OCp2.11). Fraction OCp2.11 showed a pure chromatographic profile when analyzed by both thin layer chromatography (TLC) and HPLC, furnishing the diterpene codified as Cp1 (ent-hardwickiic acid; $5.96 \mathrm{~g}$; $5.96 \%)$. Likewise, an aliquot of OCp2.8 (30.00 mg) was purified by HPLC using an analytical $\mathrm{C}_{18}$ column (Shimadzu, $4.6 \times 250 \mathrm{~mm}, 5 \mu \mathrm{m}$; isocratic mobile phase $85: 15 \mathrm{CH}_{3} \mathrm{CN}: \mathrm{H}_{2} \mathrm{O}+0.1 \%$ acetic acid; flow rate $1 \mathrm{~mL} \mathrm{~min}^{-1}$; UV detection $201 \mathrm{~nm}$ ) yielding an additional $6.0 \mathrm{mg}$ of compound Cp2 ((13E)-ent-labda-7,13-dien-15oic acid; $0.03 \%$ ).

Fractions OCp3 (3.07 g) and OCp4 (2.83 g) showed a very similar chemical profile when analyzed by HPLC, and only fraction OCp3 was submitted to phytochemical study. Thus, this fraction was chromatographed on VLC (silica gel $60 \mathrm{H} ; 300 \mathrm{~g}$ ) using increasing amounts of EtOAc (3\%) in hexanes, furnishing 12 fractions $(250 \mathrm{~mL}$ of each fraction; OCp3.1-OCp3.12), which were analyzed by TLC and HPLC. The subfraction OCp3.12 furnished a single peak chromatographic profile, which was identified as compound Cp3 (1.05 g; ent-7 $\alpha$-acetoxy hardwickiic acid; $1.05 \%$ ). Finally, the washing of OCp5 with EtOAc resulted in $348.00 \mathrm{mg}$ of the solid compound Cp4 (schistochilic acid $\mathrm{B} ; 0.348 \%$ ).

Isolation of terpenes from C. trapezifolia oleoresin

C. trapezifolia oleoresin $(16.00 \mathrm{~g}$, incorporated in about $6 \mathrm{~g}$ of silica gel $60 \mathrm{H}$ ) was initially fractionated over silica gel $60 \mathrm{H}(300.00 \mathrm{~g})$ by VLC with increasing amounts of EtOAc $(20 \%)$ in hexanes, resulting in six fractions $(1.5 \mathrm{~L}$ each; OCt1-OCt6). Fraction OCt1 was analyzed by GC-MS and the main volatile compounds were identified. Fractions OCt2 (10.96 g) and OCt3 (2.64 g) were grouped due to their very similar TLC and HPLC chemical profiles, and then were chromatographed on VLC (silica gel $60 \mathrm{H}$; $300.00 \mathrm{~g}$ ) using increasing amounts of EtOAc (3\%) in hexanes, resulting in 16 fractions $(250 \mathrm{~mL}$ of each fraction; OCt3.1-OCt3.16). Fractions OCt3.6-OCt3.10 showed the same chemical profile, and their NMR analyses allowed 
to identify the diterpene ent-hardwickiic acid, which was previously isolated from $C$. pubiflora $(\mathbf{C p 1})$. Washing the fraction OCt3 with cold hexanes resulted in $333.00 \mathrm{mg}$ off the solid diterpene $\mathbf{C t 1}$ (ent-16-hidroxy-3,13 clerodadiene15,18-dioic acid; 2.08\%).

Finally, fraction OCt3.5 (900.00 mg) was subjected to separation by classic chromatography (70 g silica gel 60 ; isocratic mobile phase: hexane/EtOAc 9:1) and 10 sub-fractions were obtained (OCt3.5.1-OCt3.5.10). The sub-fraction OCt3.5.5 (137.70 mg) was purified by repeated HPLC injections using an analytical $\mathrm{C}_{18}$ column (Shimadzu, $4.6 \times 250 \mathrm{~mm}, 5 \mu \mathrm{m}$; isocratic mobile phase $85: 15 \mathrm{CH}_{3} \mathrm{CN}: \mathrm{H}_{2} \mathrm{O}+0.1 \%$ acetic acid; flow rate $1 \mathrm{~mL} \mathrm{~min}^{-1}$; UV detection $201 \mathrm{~nm}$ ), yielding an additional $47.5 \mathrm{mg}$ of compound Ct2 (ent-labda-5,13-dien-15-oic acid; 0.29\%).

\section{Maintenance and cell culture}

The cell lines used were MCF-7 (breast adenocarcinoma), MCF-10A (normal mammary gland), ACP-01 (gastric carcinoma), A549 (lung adenocarcinoma), HeLa (human cervical cancer) and GM07492-A (normal human fibroblast). The cells were stored in liquid nitrogen $\left(-196{ }^{\circ} \mathrm{C}\right)$ in aliquots of $1 \times 10^{6}$ cells $\mathrm{mL}^{-1}$ in a freezing solution composed of $90 \%$ fetal bovine serum and $10 \%$ dimethyl sulfoxide (DMSO). The cells were grown as monolayer cultures in $5 \mathrm{~mL}$ of DMEM + HAM-F10 $(1: 1, \mathrm{v} / \mathrm{v})$ culture medium supplemented with $10 \%$ fetal bovine serum, $1 \%$ stabilized solution of antibiotics penicillin/streptomycin and $0.2 \%$ of antibiotic kanamycin solution in $25 \mathrm{~cm}^{2}$ disposable flasks, and kept at $37^{\circ} \mathrm{C}$ in an atmosphere containing $5 \% \mathrm{CO}_{2}$. The cells were subcultured every two or three days, washed using phosphate buffered saline (PBS $1 \times$ ) and detached from the inner surface of the culture flask using trypsin. Approximately $1.0 \mathrm{~mL}$ of complete culture medium was then added to the flask for trypsin inactivation, and between 50 and $100 \mu \mathrm{L}$ of the resulting cell suspension were cultured in new vials containing $5 \mathrm{~mL}$ of complete culture medium and incubated at $37^{\circ} \mathrm{C}$.

\section{Cell culture and treatment solutions}

The cultured cells were trypsinized and plated in 96-well microplates at a concentration of $1 \times 10^{4}$ cell per well in DMEM + HAM-F10 medium (1:1: v/v) supplemented with $10 \%$ fetal bovine serum and antibiotics. After $24 \mathrm{~h}$ of incubation at $37^{\circ} \mathrm{C}$ in an $5 \% \mathrm{CO}_{2}$ incubator, the cell cultures were treated with concentrations of 3.9 to $500.0 \mu \mathrm{g} \mathrm{mL}-1$ of oleoresins and 7.8 to $1000.0 \mu \mathrm{M}$ of isolated compounds. The oleoresins and compounds were solubilized in DMSO just prior to use. DMSO at $1 \%$ in culture medium was the vehicle control, and doxorubicin was used as positive control (PC). The negative control received no treatment. Each experiment was performed in triplicate.

\section{XTT assay}

The XTT assay was performed using the Cell Proliferation Kit II $24 \mathrm{~h}$ after the treatments. The culture medium was removed from the plates and the wells were washed with PBS (1×). Subsequently, $100 \mu \mathrm{L}$ of Dulbecco's modified eagle medium (DMEM) medium without red phenol containing $10 \%$ of the XTT solution (tetrazolium salt solution and electron coupling solution in the ratio 50: $1(\mathrm{v} / \mathrm{v}))$ were added to each well and the cells were incubated for $4 \mathrm{~h}$ at $37{ }^{\circ} \mathrm{C}$ in a $5 \% \mathrm{CO}_{2}$ incubator. After incubation, the absorbance was read in a 96-well plate reader at $492 \mathrm{~nm}$ (reference $690 \mathrm{~nm}$ ).

\section{Sulforhodamine B (SRB) assay}

The cell medium was completely discarded for the SRB assay and the wells were extensively washed with PBS (1x). The cells were then fixed with $25 \mu \mathrm{L}$ of $50 \%(\mathrm{~m} / \mathrm{v})$ trichloroacetic acid for $1 \mathrm{~h}$ at $4{ }^{\circ} \mathrm{C}$ and the wells were then washed four times with $100 \mu \mathrm{L}$ distilled water and allowed to dry at room temperature. Subsequently, the cellular proteins were stained by adding $50 \mu \mathrm{L}$ of $0.4 \%$ SRB $(\mathrm{m} / \mathrm{v})$ solution in $1 \%$ acetic acid (v/v) solution to each well for $15 \mathrm{~min}$ at room temperature. The excess dye was removed using $1 \%$ acetic acid solution and the plates were left to dry at room temperature. Finally, the protein-bound dye was dissolved in $150 \mu \mathrm{L}$ of $10 \mathrm{mM}$ Tris-HCl buffer ( $\mathrm{pH}$ 10.5) by stirring and quantified in a spectrophotometer at $550 \mathrm{~nm}$ with reference to $650 \mathrm{~nm}$. As in the XTT assay, the cell viability percentage was calculated considering the negative control with $100 \%$ viability.

\section{Results analysis}

The mean inhibitory concentration $\left(\mathrm{IC}_{50}\right)$ was determined by calculating the non-linear regression using the GraphPad Prism 6.07 program. ${ }^{7}$ The selectivity index (IS) was also used for data analysis and indicates selectivity of the compound between a neoplastic and a normal cell line, as well as its potential use in clinical trials. Thus, in this study, IS corresponds to the ratio between the $\mathrm{IC}_{50}$ values of the compound in the normal cells (MCF-10A or GM07492-A) and cancer cells, following the equations: IS $=\mathrm{IC}_{50} \mathrm{MCF}-10 \mathrm{~A} / \mathrm{IC}_{50} \mathrm{MCF}-7$ and $\mathrm{IS}=\mathrm{IC}_{50} \mathrm{GM} 07492-\mathrm{A} / \mathrm{IC}_{50}$ of all other tumoral cell lines. 


\section{Computational details}

The geometry optimizations, vibrational frequencies and orbital molecular calculations were performed using the Gaussian 16 package $^{8}$ at the B3LYP/6-311++G(2d,p) theory level. ${ }^{9-12}$ The nature of the stationary point was determined by inspecting the eigenvalues obtained through the Hessian matrix. The molecular volume and surface area were obtained using the HyperChem Professional 8.0 software. ${ }^{13}$ The lipophilicity (expressed as $\log \mathrm{P}_{\text {octanol/water }}$ value) was predicted using the free SwissADME web tool. ${ }^{14-16}$ Molecular superimposition was carried out using the Pymol 2.3 software. ${ }^{17}$

\section{Results and Discussion}

In this phytochemical study, 14 terpenoids were isolated and identified from the oleoresins of three different Copaifera species (Figure 1), from which eight were obtained from C. multijuga (Cm1-Cm8), four from C. pubiflora (Cp1-Cp4) and two from C. trapezifolia (Ct1-Ct2). Among these compounds, $\mathbf{C t 1}$ and $\mathbf{C t} \mathbf{2}$ are new ones and were identified by both NMR spectroscopic $\left({ }^{1} \mathrm{H}\right.$ and ${ }^{13} \mathrm{C}$ NMR, correlation ${ }^{1} \mathrm{H}-{ }^{1} \mathrm{H}$ (COSY), heteronuclear multiple quantum coherence (HMQC) and heteronuclear multiple bond correlation (HMBC)) ) and high-resolution electrospray ionization mass spectrometry (HR-ESIMS) analyses. The chemical structures of the already known terpenoids were established by comparison with previously reported spectrometric data: Cm1 (ent-3 $\beta$-acetoxy copalic acid), ${ }^{18} \mathbf{C m} 2$ (ent-3 $\beta$-hydroxy copalic acid), ${ }^{19}$ Cm3 (caryophyllene oxide), ${ }^{20} \mathbf{C m 4}$ (ent-copalic acid), ${ }^{21} \mathbf{C m 5}$ ((-)-epicubenol), ${ }^{22} \mathbf{C m 6}$ ((-)-torreyol), ${ }^{23}$ Cm7 (ent-agatic acid), ${ }^{24} \mathbf{C m 8}$ (ent-3 $\beta, 18$-dihidroxy8 (17), 13 labdadiene-15-oic acid), ${ }^{25}$ Cp1 (ent-hardwickiic acid) ${ }^{26} \mathbf{C p 2}$ ((13E)-ent-labda-7,13-dien-15-oic acid), ${ }^{27} \mathbf{C p 3}$ (ent-7 $\alpha$-acetoxy hardwickiic acid) ${ }^{28}$ and $\mathbf{C p 4}$ (schistochilic acid B). ${ }^{29}$

As previously described, the volatile compounds of these oleoresins were identified by GC-MS as sesquiterpenes from their respective hexanic fractions (OCm1, OCp1 and OCt1) (Figure 2).

Compound $\mathbf{C t 1}$ was isolated as a yellow solid. The HRESIMS analysis of $\mathbf{C t 1}$ gave an $[\mathrm{M}+\mathrm{H}]^{+}$ion at
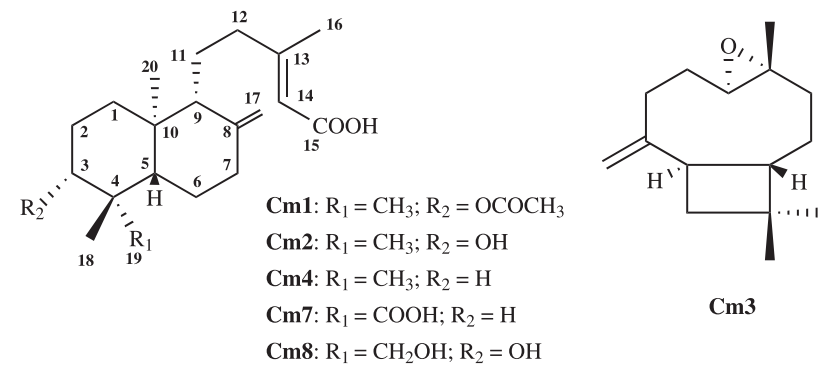

$\mathrm{Cm} 3$

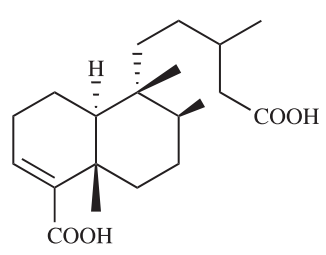

Cp4

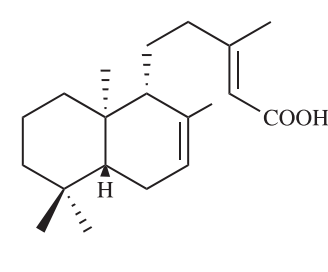

Cp2<smiles>CC1=C[C@H]2[C@@H](C(C)C)CC[C@@H](C)[C@]2(O)CC1</smiles>

Cm5

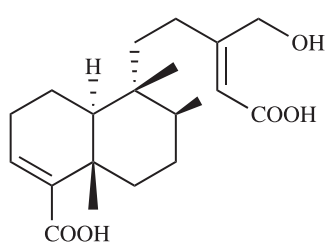

Ct1<smiles>CC1=C[C@@H]2[C@H](CC1)[C@@H](O)CC[C@@H]2C(C)C</smiles>

Cm6

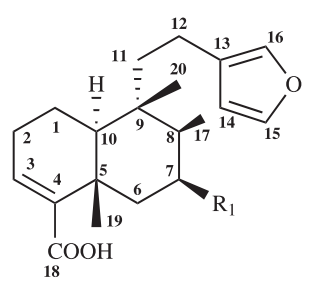

Cp1: $\mathrm{R}_{1}=\mathrm{H}$

Cp3: $\mathrm{R}_{1}=\mathrm{OCOCH}_{3}$

Figure 1. Chemical structures of terpenoids isolated from oleoresins of C. multijuga (Cm1-Cm8), C. pubiflora (Cp1-Cp4) and C. trapezifolia (Ct1-Ct2).

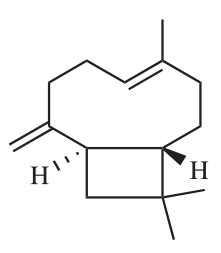

1

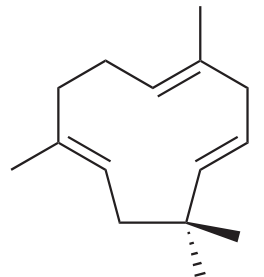

2

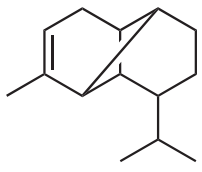

3

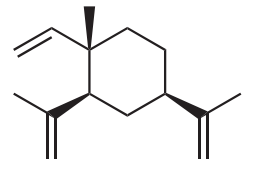

4

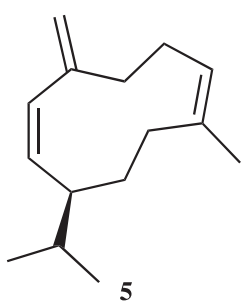

5<smiles>CC1=C(C(=O)O)C2CC=C3C(C)(C)CCC[C@]3(C)[C@@H]2CC1</smiles>

$\mathrm{Ct} 2$

Figure 2. Chemical structures of the main volatile compounds identified from oleoresins of $C$. multijuga: ( $\beta$-caryophyllene (1; 45.65\%), $\alpha$-humulene $(2 ; 15.47 \%)$, and $\alpha$-copaene $(\mathbf{3} ; 14.05 \%))$; C. pubiflora: $(\beta$-caryophyllene $(\mathbf{1} ; 27.28 \%)$, and $\beta$-elemene $(\mathbf{4} ; 17.37 \%))$; and $C$. trapezifolia: $(\beta$-caryophyllene $(\mathbf{1} ; 32.05 \%)$, germacrene D $(\mathbf{5} ; 11.00 \%)$, and spathulenol $(\mathbf{6} ; 7.5 \%))$. 
$\mathrm{m} / z 351.2183$ (calcd. 351.2171), which matched with the molecular formula $\mathrm{C}_{20} \mathrm{H}_{32} \mathrm{O}_{5}$. The ${ }^{1} \mathrm{H}$ and ${ }^{13} \mathrm{C}$ NMR data acquired for $\mathbf{C t} 1$ were similar to those previously reported for ent-hardwickiic acid (Cp1) ${ }^{26}$ a clerodanetype diterpene, commonly found in Copaifera species oleoresins. ${ }^{30}$ Therefore, the NMR data reported for Cp1 were then used to propose its chemical structure.

The ${ }^{1} \mathrm{H}$ and ${ }^{13} \mathrm{C}$ NMR data of $\mathbf{C t} \mathbf{1}$ denoted the typical chemical shifts concerning the trans-decalin ring of $\mathbf{C p 1}$, which correspond to the three methyl protons $\mathrm{H}-17\left(\delta_{\mathrm{H}}\right.$ $0.84, \mathrm{~d}, J 6.5 \mathrm{~Hz}), \mathrm{H}-19\left(\delta_{\mathrm{H}} 1.26, \mathrm{~s}\right)$ and $\mathrm{H}-20\left(\delta_{\mathrm{H}} 0.78, \mathrm{~s}\right)$, the $\mathrm{H}-3$ vinylic proton signal at $\delta_{\mathrm{H}} 6.87(\mathrm{dd}, J 4.2,3.0 \mathrm{~Hz})$ and the carboxylic acid moiety at $\mathrm{C}-18\left(\delta_{\mathrm{C}} 172.3\right)$. However, in the ${ }^{1} \mathrm{H}$ NMR spectra of $\mathbf{C t} 1$ it was not possible to observe the presence of the chemical shifts related to the furan group of the ent-hardwickiic acid, thus denoting the main chemical difference between these diterpenes.

In addition to the signals described above, the ${ }^{1} \mathrm{H}$ NMR spectra also evidenced the presence of a second vinylic proton in the chemical structure of $\mathbf{C t} 1$ resonance at $\delta_{\mathrm{H}} 7.11(1 \mathrm{H}$, brs $)$, as well as the presence of two oxymethine protons at $\delta_{\mathrm{H}} 4.79(2 \mathrm{H}, \mathrm{dd}, J 1.6,3.5 \mathrm{~Hz})$. Long-range correlations observed in the HMBC spectrum (Figure 3) between the oxymethine protons $\left(\delta_{\mathrm{H}} 4.79\right)$ and the carbons at $\delta_{\mathrm{C}} 135.2$ and 143.7 suggested the presence of another double bond between C-13/C-14 and a hydroxyl group at $\mathrm{C}-16$. Analysis of HMQC spectrum allowed to assign the signal at $\delta_{\mathrm{H}} 7.11$ with $\mathrm{H}-14$, once this proton is correlated with carbon at $\delta_{\mathrm{C}}$ 143.7. Finally, analysis of HMBC spectrum also evidenced the long-range correlation between the resonances of proton $\mathrm{H}-14\left(\delta_{\mathrm{H}} 7.11\right)$ and the carbonyl group of the carboxylic acid moiety, thus confirming the presence of this group at C-15. Compound Ct1 was therefore identified as ent-16-hidroxy-3,13-clerodadiene15,18-dioic acid. ${ }^{1} \mathrm{H},{ }^{13} \mathrm{C}$, distortionless enhancement by polarization transfer (DEPT) $135,{ }^{1} \mathrm{H}-{ }^{-1} \mathrm{H}$ COSY, HSQC and its HMBC spectra are depicted in the Supplementary Information (SI) section (Figures S1-S6). Experimental data of Ct1: ${ }^{1} \mathrm{H}$ NMR $\left(400 \mathrm{MHz}, \mathrm{CDCl}_{3}\right) \delta 1.49-1.70(\mathrm{~m}$, 2H, H-1), 1.44 (m, 2H, H-2), 6.87 (dd, 1H, J 3.0, 4.2 Hz, H-3), 2.29 (m, 2H, H-6), 1.44-1.66 (m, 2H, H-7), 1.44-1.56 (m, 1H, H-8), 1.36 (m, 1H, H-10), 1.16 (m, 1H, H-11a), 2.43 (dt, 1H, J 3.2, $12 \mathrm{~Hz}, \mathrm{H}-11 \mathrm{~b}), 1.90$ (m, 1H, H-12a), 2.19 (m, 1H, H-12b), 7.11 (brs, 1H, H-14), 4.79 (dd, 2H, $J$ 1.6, $3.5 \mathrm{~Hz}, \mathrm{H}-16), 0.84$ (d, 3H, J $6.5 \mathrm{~Hz}, \mathrm{H}-17), 1.26$ (s, 3H, H-19), 0.78 (s, 3H, H-20); ${ }^{13} \mathrm{C}$ NMR (100 MHz, $\left.\mathrm{CDCl}_{3}\right) \delta 17.6(\mathrm{C}-1), 27.4(\mathrm{C}-2), 140.5(\mathrm{C}-3), 141.5$ (C-5), 37.8 (C-5), 27.6 (C-6), 36.2 (C-7), 36.5 (C-8), 38.9 (C-9), 46.9 (C-10), 35.9 (C-11), 19.3 (C-12), 135.2 (C-13), 143.7 (C-14), 174.6 (C-15), 70.4 (C-16), 16.1 (C-17), 172.3 (C-18), 20.7 (C-19), 18.4 (C-20); HRESIMS $m / z$, calculated for $\mathrm{C}_{20} \mathrm{H}_{30} \mathrm{O}_{5}[\mathrm{M}+\mathrm{H}]^{+}:$351.2171, found: 351.2183, $[\alpha]_{\mathrm{D}}^{25}+14.0^{\circ}(c 0.004$, acetonitrile).
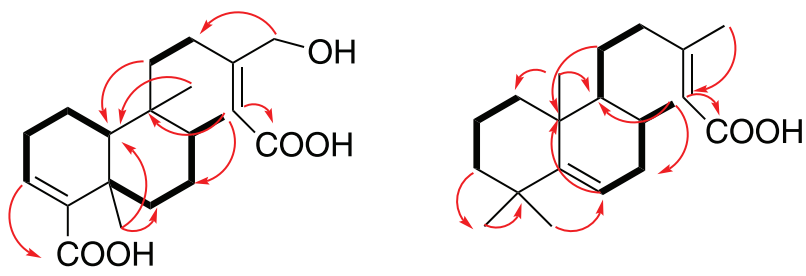

Figure 3. COSY (bonds bold) and key HMBC (arrows) correlations for Ct1 and Ct2.

Compound $\mathbf{C t} \mathbf{2}$ was isolated as a white and amorphous solid with molecular formula $\mathrm{C}_{20} \mathrm{H}_{32} \mathrm{O}_{2}$ as attested by HRESIMS $\left([\mathrm{M}+\mathrm{H}]^{+}\right.$ion at $\mathrm{m} / \mathrm{z}$ 305.2494; calculated 305.2475). The ${ }^{1} \mathrm{H}$ NMR and ${ }^{13} \mathrm{C}$ data of this compound were very similar to those reported for ent-copalic acid (Cm4). ${ }^{21}$ The ${ }^{1} \mathrm{H}$ NMR spectrum of $\mathbf{C t} \mathbf{2}$ displayed the characteristic signals of $\mathbf{C m} 4$ resonance at $\delta_{\mathrm{H}} 0.62(3 \mathrm{H}, \mathrm{s})$, $0.99(3 \mathrm{H}, \mathrm{s}), 1.05(3 \mathrm{H}, \mathrm{s}), 2.18(3 \mathrm{H}, \mathrm{s})$, and $5.70(1 \mathrm{H}$, brs), attributed to the methylic group (H-20, H-19, H-18, and $\mathrm{H}-16$ ) and to the $\mathrm{H}-14$ vinylic protons. Unlike the spectroscopic data previously reported for the diterpene ent-copalic acid, ${ }^{21}$ the ${ }^{1} \mathrm{H}$ NMR spectrum of $\mathbf{C t} 2$ revealed the presence of a vinylic proton at $\delta_{\mathrm{H}} 5.42(1 \mathrm{H}, \mathrm{brs})$ and the absence of the typical signals of $\mathrm{H}-17 \mathrm{a}\left(1 \mathrm{H}, \mathrm{brs}, \delta_{\mathrm{H}} 4.49\right)$ and $\mathrm{H}-17 \mathrm{~b}\left(1 \mathrm{H}\right.$, brs, $\left.\delta_{\mathrm{H}} 4.85\right)$, thus indicating reduction of the characteristic exocyclic double bond between C-8 and $\mathrm{C}-17$ of $\mathbf{C m} 4$. The HMBC spectrum of compound $\mathbf{C t} 2$ evidenced that the vinylic proton resonance at $\delta_{\mathrm{H}} 5.42$ is correlated with carbons at $\delta_{\mathrm{C}} 31.8,33.6$ and 37.4, which were attributed by HMQC spectrum analysis to C-7, C-8 and $\mathrm{C}-10$, thus confirming a double bond between $\mathrm{C}-5$ and C-6. Compound $\mathbf{C t} \mathbf{2}$ was therefore identified as ent5,13-labdadiene-15-oic acid, an isomer of ent-copalic acid, which has not been previously reported in the scientific literature. ${ }^{1} \mathrm{H},{ }^{13} \mathrm{C}$, DEPT $135,{ }^{1} \mathrm{H}-{ }^{1} \mathrm{H}$ COSY, HSQC and HMBC spectra of $\mathbf{C t} 2$ are depicted in the SI section (Figures S7-S12). Experimental data of $\mathbf{C t 2}$ : ${ }^{1} \mathrm{H}$ NMR (400 MHz, $\left.\mathrm{CDCl}_{3}\right) \delta 1.40-1.50(\mathrm{~m}, 2 \mathrm{H}, \mathrm{H}-1), 1.59$ (m, 2H, H-2), 1.19-1.39 (m, 2H, H-3), 5.42 (brs, 1H, H-6), 1.75-1.84 (m, 2H, H-7), 1.49 (m, 1H, H-8), $2.13(\mathrm{~m}, 1 \mathrm{H}$, H-10), 1.72 (m, 2H, H-11), 2.07 (m, 2H, H-12), 5.70 (brs, 1H, H-14), 2.18 (s, 3H, H-16), 0.81 (d, 3H, J6.7 Hz, H-17), 1.05 (s, 3H, H-18), 0.99 (s, 3H, H-19), 0.62 (s, 3H, H-20); ${ }^{13} \mathrm{C} \mathrm{NMR}\left(100 \mathrm{MHz}, \mathrm{CDCl}_{3}\right) \delta 34.9(\mathrm{C}-1), 22.4(\mathrm{C}-2), 41.1$ (C-3), 36.3 (C-5), 146.1 (C-5), 116.4 (C-6), 31.8 (C-7), 33.6 (C-8), 40.1 (C-9), 37.4 (C-10), 27.7 (C-11), 35.1 (C-12), 164.7 (C-13), 114.9 (C-14), 172.1 (C-15), 19.7 (C-16), 15.3 (C-17), 29.9 (C-18), 29.2 (C-19), 16.4 (C-20); HRESIMS $\mathrm{m} / \mathrm{z}$, calcd. for $[\mathrm{M}+\mathrm{H}]^{+}:$305.2475, found 305.2494, 
$[\alpha]_{\mathrm{D}}{ }^{25}+79.8^{\circ}\left(c 0.0157, \mathrm{CH}_{3} \mathrm{OH}\right)$. Figure 3 represents the main HMBC correlations of $\mathbf{C t} \mathbf{1}$ and $\mathbf{C t} \mathbf{2}$.

Several authors have considered the diterpene ent-copalic acid $(\mathbf{C m} 4)$ as the chemical marker of the Copaifera genus, once this metabolite has been found in oleoresins of all species of this genus. ${ }^{31}$ Despite of that, we have isolated a positional isomer of this diterpene from C. duckei oleoresin, which has never been isolated from Copaifera species before, and in which the exocyclic double bond between C-8/C-17 of $\mathbf{C m} 4$ changed for C-7/C-8. ${ }^{3}$ Additionally, another positional isomer, in which the double bound is located between C-5/C-6 (Ct2), was isolated and identified. Considering that the main analytical techniques commonly used to characterize Copaifera oleoresins are not able to distinguish these isomers, ${ }^{4}$ the discovery of yet another positional isomer of $\mathbf{C m} \mathbf{4}$ reinforces the need to establish novel diterpenes as chemical markers of Copaifera oleoresins for further application in the quality control of these important biologically active natural resources.
Concerning the biological properties of these natural resins, the cytotoxic potential of Copaifera multijuga (OCM), Copaifera pubiflora (OCP) and Copaifera trapezifolia (OCT) oleoresins, its main non-volatile metabolites (Cm1-Cm8; Cp1-Cp4; Ct1-Ct2), as well as the fractions with volatile compounds (OCm1, OCp1 and OCt1) were evaluated against a panel of tumoral (MCF-7, ACP01, A549, HeLa) and normal cell lines (MCF-10A, GM07492-A) through XTT and SRB assays (Tables 1 and 2 , respectively).

Overall, the results depicted in Tables 1 and 2 show that all three oleoresins displayed cytotoxic activity against most of the tumoral cell lines, thus collaborating with their ethnopharmacological application for the treatment of human cancer. ${ }^{1}$ In-depth analysis of these results allowed to point out that OCP displayed promising $\mathrm{IC}_{50}$ values $^{32}$ against breast adenocarcinoma cells (MCF-7; $\mathrm{IC}_{50}$ values of $\left.10.27 \pm 1.11 / 41.85 \pm 1.07 \mu \mathrm{g} \mathrm{mL}^{-1}\right)$ and tumoral gastric cancer cells $\left(\mathrm{ACP} 01 ; 21.17 \pm 1.05 / 28.75 \pm 1.06 \mu \mathrm{g} \mathrm{mL}^{-1}\right)$

Table 1. $\mathrm{IC}_{50}$ values against tumoral and normal cells displayed by Copaifera multijuga, Copaifera pubiflora and Copaifera trapezifolia oleoresins, their volatile fractions and their main isolated metabolites by using XTT (tetrazolium salt) assay

\begin{tabular}{|c|c|c|c|c|c|c|c|}
\hline & & \multicolumn{6}{|c|}{$\mathrm{IC}_{50} \pm \mathrm{SD} /\left(\mu \mathrm{g} \mathrm{mL}^{-1}\right)$} \\
\hline & & \multicolumn{4}{|c|}{ Tumoral } & \multicolumn{2}{|c|}{ Normal } \\
\hline & & A549 & ACP01 & $\mathrm{HeLa}$ & MCF-7 & GM07492-A & MCF-10A \\
\hline \multirow{3}{*}{ Oleoresins } & OCM & a & a & a & $73.12 \pm 1.10$ & a & $92.31 \pm 1.04$ \\
\hline & $\mathrm{OCP}$ & a & $28.75 \pm 1.06$ & $91.96 \pm 1.04$ & $41.85 \pm 1.07$ & a & $94.14 \pm 1.05$ \\
\hline & OCT & a & a & $91.65 \pm 1.09$ & $55.99 \pm 1.06$ & a & $79.19 \pm 1.04$ \\
\hline \multirow{3}{*}{ Volatile fractions } & OCm1 & a & $23.19 \pm 1.06$ & $54.07 \pm 1.04$ & $24.03 \pm 1.08$ & $37.42 \pm 1.06$ & $33.55 \pm 1.03$ \\
\hline & OCp1 & a & $32.69 \pm 1.11$ & $56.07 \pm 1.09$ & $22.56 \pm 1.05$ & $27.20 \pm 1.05$ & $26.84 \pm 1.04$ \\
\hline & OCt1 & $77.93 \pm 1.20$ & $80.48 \pm 1.21$ & $48.20 \pm 1.13$ & $38.40 \pm 1.06$ & $33.00 \pm 1.10$ & $36.65 \pm 1.04$ \\
\hline \multirow{15}{*}{$\begin{array}{l}\text { Isolated } \\
\text { compounds }\end{array}$} & Cm1 & a & $30.66 \pm 1.05$ & a & $67.54 \pm 1.21$ & a & a \\
\hline & $\mathrm{Cm} 2$ & a & a & a & $81.58 \pm 1.21$ & a & a \\
\hline & $\mathrm{Cm3}$ & a & a & a & a & a & a \\
\hline & $\mathrm{Cm} 4$ & a & $69.27 \pm 1.03$ & $86.34 \pm 1.08$ & a & a & a \\
\hline & $\mathrm{Cm5}$ & a & a & a & a & a & a \\
\hline & Cm6 & a & a & a & a & a & a \\
\hline & $\mathrm{Cm} 7$ & a & a & a & $63.03 \pm 1.08$ & a & a \\
\hline & $\mathrm{Cm8}$ & $\mathrm{a}$ & a & a & a & a & a \\
\hline & Cp1 & a & $56.62 \pm 1.10$ & a & $71.27 \pm 1.05$ & a & a \\
\hline & Cp2 & a & $78.17 \pm 1.08$ & $79.51 \pm 1.06$ & $94.57 \pm 1.02$ & a & a \\
\hline & Cp3 & a & a & a & a & a & a \\
\hline & Cp4 & a & a & a & $49.68 \pm 1.07$ & a & $81.16 \pm 1.05$ \\
\hline & Ct1 & a & a & $63.90 \pm 1.09$ & $39.44 \pm 1.06$ & $89.08 \pm 1.07$ & $78.12 \pm 1.05$ \\
\hline & Ct2 & $9.65 \pm 1.10$ & $11.57 \pm 1.01$ & $9.76 \pm 1.06$ & $22.56 \pm 1.03$ & a & a \\
\hline & PC (doxorubicin) & $2.40 \pm 1.31$ & $5.10 \pm 1.72$ & $0.96 \pm 0.21$ & $1.10 \pm 0.54$ & $5.8 \pm 0.95$ & $6.3 \pm 1.10$ \\
\hline
\end{tabular}

${ }^{\mathrm{a}} \mathrm{IC}_{50}$ values higher than $100.00 \mu \mathrm{g} \mathrm{mL}{ }^{-1}$. $\mathrm{IC}_{50}: 50 \%$ inhibitory concentration; SD: standard deviation; A549: lung adenocarcinoma; ACP-01: gastric carcinoma; HeLa: human cervical cancer; MCF-7: breast adenocarcinoma; GM07492-A: normal human fibroblast; MCF-10A: normal mammary gland; PC: positive control (doxorubicin). 
Table 2. $\mathrm{IC}_{50}$ values against tumoral and normal cells displayed by Copaifera multijuga, Copaifera pubiflora and Copaifera trapezifolia oleoresins, their volatile fractions and their main isolated metabolites by using SRB (sulforhodamine B) assay

\begin{tabular}{|c|c|c|c|c|c|c|c|}
\hline & & \multicolumn{6}{|c|}{$\mathrm{IC}_{50} \pm \mathrm{SD} /\left(\mu \mathrm{g} \mathrm{mL} L^{-1}\right)$} \\
\hline & & \multicolumn{4}{|c|}{ Tumoral } & \multicolumn{2}{|c|}{ Normal } \\
\hline & & A549 & ACP01 & $\mathrm{HeLa}$ & MCF-7 & GM07492-A & MCF-10A \\
\hline \multirow{3}{*}{ Oleoresins } & OCM & $54.81 \pm 1.05$ & $52.73 \pm 1.12$ & $24.61 \pm 1.04$ & $59.08 \pm 1.14$ & $19.43 \pm 1.04$ & $76.57 \pm 1.07$ \\
\hline & OCP & a & $21.17 \pm 1.05$ & $53.51 \pm 1.05$ & $10.27 \pm 1.11$ & $65.32 \pm 1.01$ & $64.28 \pm 1.05$ \\
\hline & OCT & $27.39 \pm 1.20$ & $38.65 \pm 1.19$ & $28.45 \pm 1.09$ & $29.83 \pm 1.08$ & $48.72 \pm 1.06$ & $22.79 \pm 1.04$ \\
\hline \multirow{3}{*}{ Volatile fractions } & OCm1 & $53.47 \pm 1.11$ & $15.71 \pm 1.04$ & $26.34 \pm 1.07$ & $18.84 \pm 1.06$ & $24.00 \pm 1.07$ & $23.93 \pm 1.02$ \\
\hline & OCp1 & $82.95 \pm 1.19$ & $24.50 \pm 1.14$ & $28.31 \pm 1.08$ & $19.52 \pm 1.04$ & $29.19 \pm 1.12$ & $19.34 \pm 1.07$ \\
\hline & OCt1 & $25.07 \pm 1.27$ & $34.20 \pm 1.31$ & $16.92 \pm 1.11$ & $26.59 \pm 1.04$ & $33.60 \pm 1.06$ & $28.35 \pm 1.03$ \\
\hline \multirow{15}{*}{$\begin{array}{l}\text { Isolated } \\
\text { compounds }\end{array}$} & $\mathrm{Cm} 1$ & $68.05 \pm 1.04$ & $18.30 \pm 1.13$ & $28.06 \pm 1.28$ & $32.90 \pm 1.05$ & $34.69 \pm 1.25$ & a \\
\hline & $\mathrm{Cm} 2$ & $90.34 \pm 1.04$ & $38.27 \pm 1.08$ & $42.80 \pm 1.15$ & $68.30 \pm 1.06$ & $49.45 \pm 1.18$ & a \\
\hline & $\mathrm{Cm3}$ & a & $87.43 \pm 1.12$ & a & $98.71 \pm 1.13$ & a & a \\
\hline & $\mathrm{Cm} 4$ & $66.22 \pm 1.08$ & $44.70 \pm 1.06$ & $40.05 \pm 1.09$ & $53.44 \pm 1.03$ & $38.74 \pm 1.12$ & $33.26 \pm 1.15$ \\
\hline & $\mathrm{Cm5}$ & $94.78 \pm 1.11$ & a & a & a & a & a \\
\hline & Cm6 & a & $88.32 \pm 1.24$ & a & a & a & a \\
\hline & $\mathrm{Cm} 7$ & a & a & $66.41 \pm 1.11$ & $35.15 \pm 1.08$ & $78.06 \pm 1.06$ & $59.95 \pm 1.06$ \\
\hline & $\mathrm{Cm} 8$ & a & $99.83 \pm 1.12$ & a & $a$ & a & a \\
\hline & Cp1 & a & $27.37 \pm 1.10$ & a & $21.27 \pm 1.06$ & a & $95.65 \pm 1.06$ \\
\hline & $\mathrm{Cp} 2$ & $57.36 \pm 1.12$ & $52.89 \pm 1.15$ & $37.38 \pm 1.23$ & $48.32 \pm 1.08$ & $37.55 \pm 1.08$ & $57.67 \pm 1.13$ \\
\hline & Cp3 & a & $64.01 \pm 1.21$ & $\mathrm{a}$ & $26.06 \pm 1.05$ & a & a \\
\hline & Cp4 & $71.69 \pm 1.16$ & $69.31 \pm 1.26$ & $54.67 \pm 1.13$ & $33.34 \pm 1.06$ & a & $30.18 \pm 1.08$ \\
\hline & Ct1 & $22.19 \pm 1.32$ & $13.83 \pm 1.59$ & $18.79 \pm 1.10$ & $14.31 \pm 1.10$ & $73.24 \pm 1.11$ & $91.79 \pm 1.25$ \\
\hline & Ct2 & $5.35 \pm 1.21$ & $3.57 \pm 1.12$ & $7.76 \pm 1.22$ & $11.38 \pm 1.07$ & $97.13 \pm 1.14$ & $98.12 \pm 1.23$ \\
\hline & PC (doxorubicin) & $1.7 \pm 0.89$ & $4.52 \pm 1.27$ & $0.85 \pm 0.3$ & $0.89 \pm 0.22$ & $4.32 \pm 0.93$ & $3.7 \pm 0.84$ \\
\hline
\end{tabular}

${ }^{\mathrm{a}} \mathrm{IC}_{50}$ values higher than $100.00 \mu \mathrm{g} \mathrm{mL}{ }^{-1}$. $\mathrm{IC}_{50}: 50 \%$ inhibitory concentration; SD: standard deviation; A549: lung adenocarcinoma; ACP-01: gastric carcinoma; HeLa: human cervical cancer; MCF-7: breast adenocarcinoma; GM07492-A: normal human fibroblast; MCF-10A: normal mammary gland; PC: positive control (doxorubicin); SRB: sulforhodamine B.

when investigated through SRB and XTT assays. It is also important to observe that the selective indexes of OCP obtained in $\mathrm{ACP} 01\left(\mathrm{IC}_{50}\right.$ values of $\mathrm{GM} 07492-\mathrm{A} / \mathrm{IC}_{50}$ values of ACP01) and MCF-7 ( $\mathrm{IC}_{50}$ values of MCF-10A / $\mathrm{IC}_{50}$ values of MCF-7) cell lines were higher (values ranged from 2.25 to 6.26 ) than those suggested as promising in the literature. ${ }^{32}$

Considering the results displayed by the oleoresins against the tumoral cell lines, ${ }^{32}$ it became relevant to individually evaluate the cytotoxic potential of their chemical constituents, aiming to select the main metabolites responsible for this activity. The fractions containing the volatile terpenoids $(\mathrm{OCm} 1, \mathrm{OCp} 1$ and $\mathrm{OCt} 1)$ were investigated for the first time and as shown in Tables 1 and 2, these fractions displayed $\mathrm{IC}_{50}$ values that can be considered promising according to Suffness and Pezzuto. ${ }^{32}$ However, it was noted that these volatile terpenoids are not selective considering their selective indexes lower than 2 , once
OCm1, OCp1 and OCt1 promoted in vitro antiproliferative effects against tumoral and normal cells viability with very close $\mathrm{IC}_{50}$ values.

Regarding the 14 non-volatile terpenoids isolated and identified in this study, most $\mathrm{IC}_{50}$ values displayed by these compounds were above the criteria to be considered as a lead compounds in the discovery of new anticancer agents $\left(\mathrm{IC}_{50}\right.$ values higher than $10.0 \mu \mathrm{g} \mathrm{mL} \mathrm{mL}^{-1},{ }^{32}$ except for the new diterpene $\mathbf{C t} \mathbf{2}$, which displayed relevant cytotoxic effect against most of the tumoral cell lines $\left(\mathrm{IC}_{50}\right.$ values ranging from $3.57 \pm 1.12$ to $22.56 \pm 1.03 \mu \mathrm{g} \mathrm{mL}^{-1}$; Tables 1 and 2) and a high selectivity level in both XTT and SRB assays.

As described above, the phytochemical study performed with these oleoresins allowed to isolate and identify three different double bond position isomers $(\mathrm{Cm} 4, \mathrm{Cp2}$ and Ct2). It is interesting to point out that the diterpenes $\mathrm{Cm} 4$ and $\mathbf{C p 2}$ displayed moderate cytotoxic activity and very 
similar $\mathrm{IC}_{50}$ values, whilst the diterpene $\mathbf{C t} \mathbf{2}$ showed to be very promising. ${ }^{32}$

Computational calculations were used to perform a qualitative comparative analysis for compounds $\mathbf{C t} \mathbf{2}$, Cp2 and $\mathbf{C m} 4$, in order to correlate possible structural differences between the compounds and their biological activities. Preliminary quantitative structure-activity relationship (QSAR) approaches developed by our research group and involving diterpenes indicated that in vitro cytotoxicity of ent-kaurenoic acid derivatives against human breast carcinoma cell line may be related to its $\log \mathrm{P}$ (lipophilicity), as well as to electronic parameters (HOMO and HOMO-1 molecular orbital energies), thus, suggesting that the interaction between these derivatives and the cell involves charge displacement and can occur by any kind of intermolecular interaction. ${ }^{33} \mathrm{~A}$ high value of $\mathrm{HOMO}$ (highest occupied molecular orbital) energy $\left(\mathrm{E}_{\text {номо }}\right)$ means large ease for electrons donation. On the other hand, a low value of LUMO (lowest unoccupied molecular orbital) energy $\left(\mathrm{E}_{\mathrm{LUMO}}\right)$ indicates large facility for electrons acceptance. Thus, the energy difference between HOMO and LUMO $\left(\Delta \mathrm{E}_{\text {gap }}\right)$ is related to the chemical stability. ${ }^{34,35}$ HOMO, HOMO- 1 and LUMO representation of compounds $\mathrm{Cm} 4, \mathrm{Cp} 2$ and Ct2 and the values of $\mathrm{E}_{\text {номо }}, \mathrm{E}_{\mathrm{Lumo}}$ and $\Delta \mathrm{E}_{\text {gap }}$ are shown in the SI section (Figure S13 and Table S1, respectively). Interestingly, for the three compounds, the HOMO orbital is mainly distributed over the double bond in the trans-decalin ring, while LUMO and HOMO-1 are localized more in the side chain containing the carboxylic acid group. Although the distribution of molecular orbitals is similar, the $\Delta \mathrm{E}_{\text {gap }}$ indicates that $\mathrm{Ct} \mathbf{2}$ is more polarizable than $\mathrm{Cp} 2$ and $\mathrm{Cm} \mathbf{4}$, a factor that may usually be associated with a high chemical reactivity and low kinetic stability. ${ }^{36}$ Regarding lipophilicity, no significant differences in $\log \mathrm{P}$ values were observed between the three compounds. Spatial characteristics can also be important to explain the great difference between the $\mathrm{IC}_{50}$ values shown by these compounds. In this sense, Ct2 presented smaller surface area, molecular volume and dipole moment than $\mathbf{C p 2}$ and $\mathbf{C m} \mathbf{4}$ (Table S1, SI section). A molecular superimposition evaluation considering the equilibrium geometries of these compounds indicated that Cp2 and $\mathbf{C m} 4$ presented a very close spatial conformation, which is distinct from that observed for Ct2 (Figure 4). This factor can also be relevant to explain the higher activity of Ct 2 in comparison with the results shown by $\mathbf{C p} 2$ and $\mathbf{C m} 4$.

Finally, it is important to report that the apparently better results obtained in the SRB assay (Table 2) in comparison with those of the XTT assays may be due to the fact that SRB stains the total protein content of the cell and does not depend on the cellular metabolism. Therefore, lower $\mathrm{IC}_{50}$ values might be observed in the SRB assay in comparison

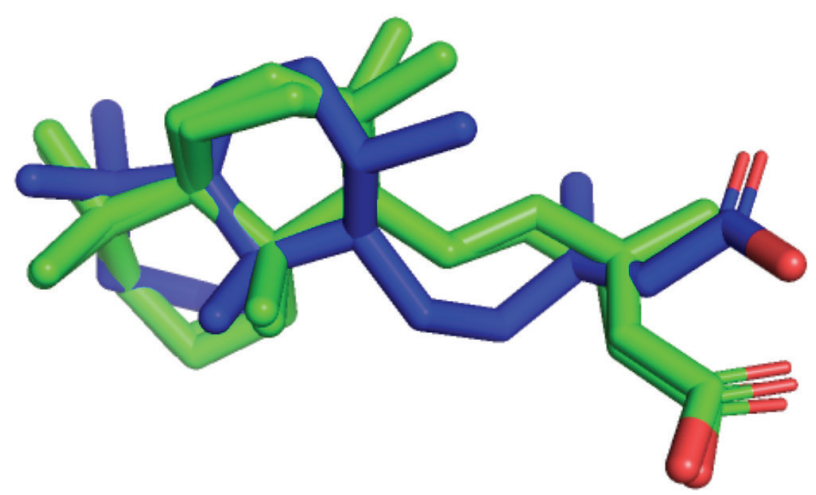

Figure 4. Molecular superimposition of diterpenes Ct2 (blue), Cp2 (green), and $\mathrm{Cm} 4$ (green).

with the XTT assay. ${ }^{37}$ Moreover, the XTT assay have the disadvantage of being more susceptible to variations in cellular levels of nicotinamide adenine dinucleotide (NADH), glucose and other factors than the SRB assay, which is one of the reasons why it was adapted by the National Cancer Institute for its screening programme. ${ }^{38}$

\section{Conclusions}

The present study lead to the isolation and identification of 14 diterpenes from three different Copaifera oleoresins (C. multijuga, C. pubiflora, and C. trapezifolia). Compounds ent-16-hidroxy-3,13 clerodadiene-15,18-dioic acid (Ct1) and ent-labda-5,13-dien-15-oic acid (Ct2) have not been previously reported in the scientific literature. Our findings also revealed the existence of a third position isomer of the metabolite that is considered by the literature as the chemical marker of the Copaifera genus (copalic acid; Cm4), thus denoting the need to establish additional diterpenes as chemical markers of Copaifera oleoresins for further application in the quality control of these important biologically active natural resources. It was possible to conclude through the cytotoxic studies that the most active compound was the new diterpene $\mathbf{C t} \mathbf{2}$, which displayed relevant cytotoxic effect against most of the tumoral cell lines and a high selectivity level in both XTT and SRB assays.

\section{Supplementary Information}

Supplementary data (NMR and computational details) are available free of charge at http://jbcs.sbq.org.br as PDF file.

\section{Acknowledgments}

This study was financed in part by the Coordenação de Aperfeiçoamento de Pessoal de Nível Superior-Brazil 
(CAPES) Finance Code 001. The authors thank São Paulo Research Foundation (FAPESP) for the financial support, grants 2011/13630-7 and 2016/01232-0. SRA, RCSV and RLTP thank CNPq (306441/2017-9, 306432/2017-0 and 313648/2018-2, respectively) for the research fellowships. RLTP thanks CAPES for financial support.

\section{Author Contributions}

LJC and MFCS performed the isolation and identification of 14 terpenoids from oleoresins obtained from three different Copaifera species (C. multijuga, C. pubiflora and C. trapezifolia); LJC, TOT and MOG were responsible for the cytotoxicity assays; JJMS and AEMC performed the identification of the main volatile compounds by GC-MS; RPO and RLTP were responsible for the computational investigations; SRA, RCSV, JKB and RAS designed the study, supervised the laboratory work and contributed to critical reading of the manuscript.

\section{References}

1. Arruda, C.; Mejia, J. A. A.; Ribeiro, V. P.; Borges, C. H. G.; Martins, C. H. G.; Veneziani, R. C. S.; Ambrosio, S. R.; Bastos, J. K.; Biomed. Pharmacother. 2019, 109, 1.

2. Bardají, D. K. R.; da Silva, J. J. M.; Bianchi, T. C.; Eugênio, D. S.; de Oliveira, P. F.; Leandro, L. F.; Rogez, H. L. G.; Venezianni, R. C. S.; Ambrosio, S. R.; Tavares, D. C.; Bastos, J. K.; Martins, C. H. G.; Anaerobe 2016, 40, 18.

3. Borges, C. H. G.; Cruz, M. G.; Carneiro, L. J.; da Silva, J. J. M.; Bastos, J. K.; Tavares, D. C.; de Oliveira, P. F.; Rodrigues, V.; Veneziani, R. C. S.; Parreira, R. L. T.; Caramori, G. F.; Nagurniak, G. R.; Magalhães, L. G.; Ambrósio, S. R.; Chem. Biodiversity 2016, 13, 1348.

4. Carneiro, L. J.; Bianchi, T. C.; da Silva, J. J. M.; Oliveira, L. C.; Borges, C. H. G.; Lemes, D. C.; Bastos, J. K.; Veneziani, R. C. S.; Ambrosio, S. R.; J. Braz. Chem. Soc. 2018, 29, 729.

5. Lima, S. R. M.; Veiga Jr., V. F.; Christo, H. B.; Pinto, A. C.; Fernandes, P. D.; Phytother. Res. 2003, 17, 1048.

6. Gomes, N. D.; Rezende, C. D.; Fontes, S. P.; Hovell, A. M. C.; Landgraf, R. G.; Matheus, M. E.; Pinto, A. D.; Fernandes, P. D.; J. Ethnopharmacol. 2008, 119, 179.

7. GraphPad Prism, version 6.07; GraphPad Software Inc., San Diego, USA, 2015.

8. Frisch, M. J.; Trucks, G. W.; Schlegel, H. B.; Scuseria, G. E.; Robb, M. A.; Cheeseman, J. R.; Scalmani, G.; Barone, V.; Mennucci, B.; Petersson, G. A.; Nakatsuji, H.; Caricato, M.; Li, X.; Hratchian, H. P.; Izmaylov, A. F.; Bloino, J.; Zheng, G.; Sonnenberg, J. L.; Hada, M.; Ehara, M.; Toyota, K.; Fukuda, R.; Hasegawa, J.; Ishida, M.; Nakajima, T.; Honda, Y.; Kitao, O.; Nakai, H.; Vreven, T.; Montgomery Jr., J. A.; Peralta, J.;
Ogliaro, F.; Bearpark, M.; Heyd, J. J.; Brothers, E.; Kudin, K. N.; Staroverov, V. N.; Keith, T.; Kobayashi, R.; Normand, J.; Raghavachari, K.; Rendell, A.; Burant, J. C.; Iyengar, S. S.; Tomasi, J.; Cossi, M.; Rega, N.; Millam, J. M.; Klene, M.; Knox, J. E.; Cross, J. B.; Bakken, V.; Adamo, C.; Jaramillo, J.; Gomperts, R.; Stratmann, R. E.; Yazyev, O.; Austin, A. J.; Cammi, R.; Pomelli, C.; Ochterski, J. W.; Martin, R. L.; Morokuma, K.; Zakrzewski, V. G.; Voth, G. A.; Salvador, P.; Dannenberg, J. J.; Dapprich, S.; Daniels, A. D.; Farkas, O.; Foresman, J. B.; Ortiz, J. V.; Cioslowski, J.; Fox, D. J.; Gaussian 09, Revision C.01; Gaussian, Inc., Wallingford, CT, 2009.

9. Becke, A. D.; J. Chem. Phys. 1993, 98, 5648.

10. Krishnan, R.; Binkley, J. S.; Seeger, R.; Pople, J. A.; J. Chem. Phys. 1980, 72, 650.

11. Lee, C. T.; Yang, W. T.; Parr, R. G.; Phys. Rev. B 1988, 37, 785. 12. Mclean, A. D.; Chandler, G. S.; J. Chem. Phys. 1980, 72, 5639.

13. HyperChem (TM) Professional, 8.0; Hypercub Inc., USA, 2019. 14. Daina, A.; Michielin, O.; Zoete, V.; Sci. Rep. 2017, 7, 42717.

15. Daina, A.; Zoete, V.; ChemMedChem 2016, 11, 1117.

16. El Kerdawy, A. M.; Osman, A. A.; Zaater, M. A.; J. Mol. Model. 2019, 25, 171.

17. Schrodinger; Pymol, 2.3; Schrodinger, USA, 2019.

18. Braun, S.; Breitenbach, H.; Tetrahedron 1977, 33, 145.

19. Romero, A. L.; Baptistella, L. H. B.; Imamura, P. M.; J. Braz. Chem. Soc. 2009, 20, 1036.

20. Moreira, I. C.; Roque, N. F.; Contini, K.; Lago, J. H. G.; Rev. Bras. Farmacogn. 2007, 17, 55.

21. Ohsaki, A.; Yan, L. T.; Ito, S.; Edatsugi, H.; Iwata, D.; Komoda, Y.; Bioorg. Med. Chem. 1994, 4, 2889.

22. Ohta, Y.; Hirose, Y.; Tetrahedron Lett. 1967, 2073.

23. Oyarzun, M. L.; Garbarino, J. A.; Phytochemistry 1988, 27, 1121.

24. Zdero, C.; Bohlmann, F.; King, R. M.; Phytochemistry 1991, 30, 2991.

25. Jakupovic, J.; Baruah, R. N.; Bohlmann, F.; King, R. M.; Robinson, H.; Tetrahedron 1985, 41, 4537.

26. Mcchesney, J. D.; Clark, A. M.; Silveira, E. R.; J. Nat. Prod. 1991, 54, 1625.

27. Xiang, W.; Li, R. T.; Song, Q. S.; Na, Z.; Sun, H. D.; Helv. Chim. Acta 2004, 87, 2860.

28. Heymann, H.; Tezuka, Y.; Kikuchi, T.; Supriyatna, S.; Chem. Pharm. Bull. 1994, 42, 1202.

29. Tori, M.; Masuya, T.; Asakawa, Y.; Phytochemistry 1993, 32, 1229.

30. da Silva, J. J. M.; Crevelin, E. J.; Carneiro, L. J.; Rogez, H.; Veneziani, R. C. S.; Ambrósio, S. R.; Beraldo Moraes, L. A.; Bastos, J. K.; J. Chromatogr. A 2017, 1515, 81.

31. Souza, A. B.; Moreira, M. R.; Borges, C. H. G.; Simão, M. R.; Bastos, J. K.; de Sousa, J. P. B.; Ambrosio, S. R.; Veneziani, R. C. S.; Biomed. Chromatogr. 2013, 27, 280. 
32. Suffness, M.; Pezzuto, J. M. I. E. In Methods in Plant Biochemistry, Assays for Bioactivity, vol. 6, Academic Press: London, 1991, p. 71.

33. da Costa, R. M.; Bastos, J. K.; Costa, M. C. A.; Ferreira, M. M. C.; Mizuno, C. S.; Caramori, G. F.; Nagurniak, G. R.; Simao, M. R.; dos Santos, R. A.; Veneziani, R. C. S.; Ambrosio, S. R.; Parreira, R. L. T.; Phytochemistry 2018, 156, 214.

34. Karelson, M.; Lobanov, V. S.; Katritzky, A. R.; Chem. Rev. 1996, 96, 1027.

35. Srivastava, A. K.; Pandey, A. K.; Jain, S.; Misra, N.; Spectrochim. Acta, Part A 2015, 136, 682.
36. Abbaz, T.; Bendjeddou, A.; Villemin, D.; Pharm. Biol. Eval. 2018, 5, 27.

37. Henriksson, E.; Kjellen, E.; Wahlberg, P.; Wennerberg, J.; Kjellstrom, J. H.; In Vitro Cell. Dev. Biol.: Anim. 2006, 42, 320.

38. Taylor, P.; Colman, L.; Bajoon, J.; J. Ethnopharmacol. 2014, $158,246$.

Submitted: October 18, 2019 Published online: March 26, 2020 